\title{
Influence Of Young Farmers' Club Of Kenya Activities On Secondary School Students' Performance In Kenya Certificate Of Secondary Education Agriculture in Rongai Sub-County Of Nakuru County, Kenya
}

\author{
${ }^{1}$ David Njoroge, ${ }^{2}$ Prof. John Gowland Mwangi, ${ }^{3}$ Dr. Maurice O. Udoto \\ 123, Department of Agricultural Education and Extension, Egerton University P.O. Box 536-20115, Egerton, \\ Kenya.
}

\begin{abstract}
Young Farmers' Club (YFC) activities are vital in the mastery and attainment of skills in the agriculture subject since it is best found out by practicing. Increased youth participation in agricultural production is necessary and vital in facilitating food and nutritional security. The primary objective of YFCK is to train young people to be productive future farmers. Since secondary school education is terminal to the majority of the youth, non-attainment of lifelong skills in agriculture may lead to low standards of living and a decline in agricultural productivity. The study sought to demonstrate the influence of YFCK activities on secondary school students' performance in KCSE Agriculture in Rongai Sub-County. It employed a crosssectional survey design to collect data from a target population of 1,506 YFCK members in 30 public secondary schools. Purposive sampling method was used to select eight secondary schools to represent all the types and categories of schools in the four Divisions of the Rongai Sub-County. Proportionate sampling method was then used to obtain a sample of 175 YFCK members. All the 13 Agriculture teachers were used for data analysis. Questionnaires validated by two experts from the Department of Agricultural Education and Extension of Egerton University were used to collect data. Reliability of the instrument was estimated through a pilot-test using 50 YFCK members of the Jomo Kenyatta secondary school in the Nakuru North Sub-County. It achieved a reliability coefficient of 0.72 and 0.73 for YFCK members and Agriculture teachers respectively, at a significance level of $\alpha=0.05$. Data was collected using questionnaires administered to Agriculture teachers and YFCK members. Computations were carried out using the Statistical Package for the Social Sciences (SPSS). The outcome of the study indicated that there was no statistically significant difference between the mean scores in KCSE Agriculture of schools with active and non-active YFCK. Participation in YFCK was limited for schools in the study. The KCSE Agriculture mean scores for schools in the study were higher than the overall schools mean scores between 2008 and 2012. The researcher recommends that Agriculture teachers in liaison with school administration should enhance YFCK activities. This is for effective practical activities in teaching and learning of agriculture subject according to the syllabus.
\end{abstract}

Key Words: Academic performance, Agriculture teacher, Young Farmer, Young Farmers' Club

\section{Introduction}

Mobilizing the youths for national development is a common phenomenon amongst the western and developing nations. In such nations as Great Britain, Netherlands, Denmark, Germany, The United States of America and Tanzania, the participation of youths in agricultural production through youth programs had contributed significantly to agricultural growth and empowering the citizenry (Daudu, Okwoche, \& Adegboye, 2009). Many young people view farming as hard, backbreaking and dirty work with little self-esteem (Mangal, 2009). Young Farmers' Clubs can help youth see farming as a dignified profession from which people can make a decent livelihood and not where the practitioners are condemned to poverty (Olujide, 2008).In many developed states, Young Farmers' Clubs are active and well established for instance; the Dominion Federation of Young Farmers' Clubs (DFYFC) has served to establish Young Farmers' Clubs throughout New Zealand (McLintock, 2009). Canada takes in its own 4-H program, which broadcasts data on new farming methods and maintains experimental farms, research stations, and research institutions throughout the country. In Australia, each state has several agricultural research stations and an extension service. Great Britain has a program of youth clubs called a Young Farmer's Clubs that resemble 4-H (National 4-H, 2012). In England and Wales YFC, activities encompass agriculture, athletics, community volunteering, environment, and social activities (National Federation of Young Farmers' Clubs [NFYFC], 2011). According to Hantos (2010) in the rural policies of the European Union (EU), more emphasis has been made in the past 5-10 years to support bills that target at making farming more attractive for new people. In the United States of America agricultural education at the high school, level focuses on three chief categories: classroom instruction, Supervised Agricultural Experience (SAE), and active participation in the National FFA Organization (Future Farmers of America) 
(NFYFC, 2011). Classroom instruction of an agricultural class teaches the students the basic concepts of the particular course through hands on learning and experience. Another essential for agricultural teaching at the high school level is the Young Farmers Association group, which is a prerequisite for the teacher, not the students (Phipps, Osborne, Dyer, \& Ball, 2008). The group usually meets monthly and consists of all the local farmers, citizens, or anyone interested in finding out more about agriculture and new farming methods. The Young Farmers Association was designed thus that the technologies created in the agricultural field would be presented and utilized in the economy. It likewise passed the agricultural teachers the opportunity to satisfy the local citizens and gain out the community (Phipps et al., 2008). The National Federation of Young Farmers' Clubs (NFYFC) memberships comprise of young people aged between 10 and 26 years. The calendar of FFA program in the USA usually covers a 12-month period (NFYFC, 2011). Schools go by the timetables created by agriculture; summer vacation exists for students to have adequate time to help in their parent's farm (Texas Young Farmers, 2007).In Ghana, the Youth in Agriculture Program (YIAP) is a Government of Ghana agricultural sector initiative with an objective of motivating the youth to accept and appreciate farming as a commercial venture, thereby taking up farming as a lifetime vocation (Ministry of Food and Agriculture [MOFA], 2013). The YIAP has the task and responsibility of rallying the young to take up farming and its other related natural processes as a lifetime vocation through the provision of tractor services and agro-inputs. YIAP has the aim of making youth accept farming as a commercial business venture; Generate appreciable income to meet farmer's domestic and personal needs and improve the standard of livelihood of the youth through improved income (MOFA, 2013). In Nigeria, Young Farmers' Club is an organization in which young people (9-20 years) are encouraged to learn about better farming and homemaking. The members are under the guidance of the agriculture teachers, agricultural extension personnel and local volunteer leaders (Adebo, 2009). In Kenya, YFCK were established to help boys and girls to develop ideas for better farming, provide social and recreational activities, help give the necessary dignity to agriculture as an occupation and develop good and competent agricultural leadership. The YFCK are associations whose member's age range from 15-24 years drawn from secondary schools and tertiary institutions. These clubs operate under the aegis of the Agricultural Society of Kenya (ASK), whose primary purpose is to monitor their activities and to record them for administrative purposes (Agili, 2007). The objectives of YFCK include promoting interest in farming, sound training in advanced methods of crop and animal husbandly, leadership skills, self-reliance, self-confidence and responsibility (Lewa \& Ndung'u, 2011). In the 1960s, the Kenya Government incorporated agricultural education in secondary school curricula with the intention to acquaint students to modern agriculture methods, careers, and as a means of creating students interest in farming (Mbaga, 1996). In order to make youth selfreliant, agriculture subject was made compulsory in both primary and secondary schools in 1985, following recommendations by the Mackay commission. School agriculture is thus an effort to instill values, attitudes, knowledge as well as practical skills in learners, which are required to improve agricultural production (Nyangau, Kibet, \& Ngesa, 2011). In summation, this was in line with secondary school training in Kenya whose aim were to conform to the demands of the students who terminate their training after secondary school and those who moved along with tertiary training and other professional training or exercise. According to Ojediran (as cited in Daudu, Okwoche, and Adegboye, 2009) for a country to reach economic stability the agricultural sector must be vibrant thus youths are encouraged to consider farming as a noble profession. Efforts should be made to change the negative perception the youth have about agriculture, as a profession for the uneducated and unskilled laborers with extremely low economic return (MOFA, 2013). The youth is the ideal catalyst for change, given their greater prosperity and willingness to adapt new ideas, concept and technology, which are important to changing how agriculture is practiced and perceived (Young People and Agriculture, 2009). Youths migrate to urban areas in order to reach up for things that are lacking in rural areas (Adebo, 2009). This leaves the majority of work in agriculture to old human races, contributing to low productivity, low income and hence the evil cycle of impoverishment and food insecurity (Mangal, 2009). Lack of financial backing to better productivity and bring innovation in the sector has pushed out young people from business opportunities in farming into other sectors such as Information and Communication Technology (ICT). If youth are to choose careers in agriculture, the sector has to be financially rewarding, modern and challenging (Mutambo, 2011). More awareness of agricultural opportunities can be promoted through educational trips to model farms, research centers and invigorating the YFCK in secondary schools and 4-K Clubs in primary schools. Whereas rural schools may have the land for farming, urban schools could explore other activities that do not require a lot of land, such as balcony farming, floriculture, poultry, rabbit rearing, fish farming and agro processing (Lewa \& Ndung'u, 2011).

\section{Statement of the Problem}

Practical activities are vital in the teaching of agricultural education; therefore, it is important to determine the influence of YFCK activities on secondary school students' performance in KCSE Agriculture. Inadequate practical activities in agriculture subject make learners not to be properly acquainted with knowledge 
and technical skills. This is because agriculture is a practical oriented subject that is best learned by practicing. Granted that, secondary school education is terminal to the bulk of the students; it might lead to the nonattainment of lifelong skills, low living standards and eventually, a decline in agricultural output. YFCK activities have the potential to assist secondary school agriculture students' apply agricultural practices and principles during their examinations, culminating in better performance in KCSE Agriculture, self-reliance and economic growth.

\section{Purpose of the Study}

The purpose of the study was to determine the influence of YFCK activities on secondary school students' performance in KCSE Agriculture in Rongai Sub-County of Nakuru County.

\section{Objectives of the Study}

The objectives of the study were to:

i Determine the status of YFCK in selected secondary schools in Rongai Sub-County;

ii Determine the main YFCK activities in selected secondary schools in Rongai Sub-County;

iii Compare the performance in KCSE Agriculture between active and non-active YFCK in selected secondary schools in Rongai Sub-County.

\section{Research Questions}

The following Research Questions and null hypothesis guided the study:

i What was the status of YFCK in selected secondary schools in Rongai Sub-County?

ii What were the main YFCK activities in selected secondary schools in Rongai Sub-County?

\section{Hypothesis of the Study}

$\mathrm{H}_{01}$ : There is no statistically significant difference between the mean scores in KCSE Agriculture of schools with active and non-active YFCK.

\section{Theoretical Framework}

The research focused on the level of YFCK activities and their influence on performance in KCSE Agriculture. The study was guided by David Kolb's (1984) Experiential Learning Theory (ELT), which sought to explain the influence of learning by doing. Experiential learning theory defines learning as the process whereby knowledge was created through the transformation of experience. According to Sternberg and Zhang (2000), the theory was called experiential learning to emphasize on the central role that experience plays in the learning process. Experiential Learning Theory (ELT) is learner-centered and operates on the premise that individuals learn best through experience (Conlan, Grabowski \& Smith, 2003). Experience provides relevance to the education process. Dewey (1916) stated that, "An ounce of experience is better than a ton of theory simply because it is only with experience that any theory has a vital and verifiable significance" (Cheek et al., 2010 p. 2). On secondary school agriculture, Longshal and Usman (2009) emphasize on learning by doing, this is because agriculture is a practical-oriented subject. Students are given a chance to utilize the principles they had learned in class and apply them to real life situations (Cheek et al., 2010). Participating in the various activities of YFCK may lead to improved learning, student personal development and career development. YFCK activities present an opportunity to move outside of the classroom into relevant agricultural contexts, thus facilitating learning by doing. This was best summarized by a maxim by Benjamin Franklin, 1750 "Tell me and I forget, Teach me and I remember, Involve me and I will learn" (Northern Illinois University, 2011). Students should participate completely in the learning process and have control over its nature and direction. Therefore, teachers and students of agriculture should also move beyond the 'doing' and ensure all learning is linked to thinking and knowledge that will easily be applied later in life. Baker and Robinson (2012) argued that, classroom and laboratory experiences, including guest speakers, research projects, science experiments, green house or school farm work, and group projects provide the impetus for the Experiential Learning process. Experiential Learning experiences help to complete student's preparation for their chosen careers, which reinforce course content and theory. Students learn through student- rather than instructor-centered experiences by doing, discovering, reflecting and applying. Through these experiences, students develop communication skills, self-confidence, and gain and strengthen decision-making skills by responding to and solving real world problems and processes (Northern Illinois University, 2011). SAE programs give students the opportunity to take the information learned in the classroom setting and use it on an agricultural topic that interests them. This portion of an agricultural education will give students an idea of how it is working out in the real world and solving problems that will arise in the work field (Phipps et al., 2008). 


\section{Location of the Study}

The study covered Rongai Sub-County, which is one of the nine Sub-County's of Nakuru County. It comprises of four administrative Divisions; Ngata, Kampi ya Moto, Rongai and Solai. The Sub-County headquarters is at Kampi Ya Moto. It boarders Nakuru North Sub-County to the East, Njoro Sub-County to the West, Baringo County to the North and Nakuru town Sub-County to the South. The area is arid with the main economic activity being sisal production. However, it has a progressive livestock sector, especially dairy cattle, goats and bee industry. Tourist attraction sites include Menengai crater and Lake Solai. The elevation is about $1,912 \mathrm{~m}$ above sea level. The rainfall amount registered was 800-1600 $\mathrm{mm}$ per year. The long rains are experienced between March and June and short rains between October and November. Rongai Sub-County occupies an area of $1,349.71 \mathrm{~km}^{2}$, which is $18.8 \%$ of Nakuru County land area (Modern Rongai Constituency Strategic Plan [MRCSP], 2011). The population is 163,864 (50.44\% female and $49.56 \%$ male) with a population density of 391 people per $\mathrm{km}^{2}$. Poverty prevalence in rural areas is $44 \%$, while urban poverty is $47 \%$. It contributes $2.5 \%$ to the National Poverty index (MRCSP, 2011). The locale was appropriate for the study because the researcher is knowledgeable about schools in the Sub-County, where he had previously worked with the TSC. In addition, no similar studies had been carried out before in the area. (MOE Rongai, 2013).

\section{Methodology}

A cross-sectional survey was used to establish the influence of YFCK activities on secondary school students' performance in KCSE Agriculture in Rongai Sub-County. According to Bowling and Ebrahim, (2005) a cross-sectional survey obtains information from a given population on many variables at one point in time. The study covered the period between 2008 and 2012. The researcher preferred this design since the study would largely seek information regarding self-reported facts about the respondent's feelings, opinions, attitudes and beliefs on the current situation in comparison with the influence of YFCK activities on students' performance in KCSE Agriculture in Rongai Sub-County (Kendall, 2007). Table 1 shows population distribution. The target population of the study was 1,506 YFCK members in 30 public secondary schools in Rongai Sub-County (MOE, 2011). There were 54 agriculture teachers comprising 21 male and 33 female. The Sub-County had two Boys Boarding schools, two Girls Boarding schools, 1 Mixed Day/Boarding school and 25 Mixed Day secondary schools.

Table 1: Summary of the Population of Study Distribution

\begin{tabular}{|c|c|c|c|}
\hline Type of school & $\begin{array}{l}\text { No. of } \\
\text { Schools }\end{array}$ & $\begin{array}{l}\text { No. of Agric } \\
\text { Teachers }\end{array}$ & $\begin{array}{l}\text { No. of YFCK } \\
\text { members }\end{array}$ \\
\hline Boys Boarding & 2 & 4 & 114 \\
\hline Girls Boarding & 2 & 4 & 62 \\
\hline Mixed Boarding & 1 & 2 & 80 \\
\hline Mixed Day & 25 & 44 & 1,250 \\
\hline Total & 30 & 54 & 1,506 \\
\hline
\end{tabular}

Source: MOE, 2011 Rongai Sub-County Annual Report

Purposeful sampling method was used to select eight public secondary schools; two Girls' Boarding schools, four Mixed Day secondary schools, one Mixed Boarding school and one Boys' Boarding school. All the schools selected had administered KCSE Agriculture examination over the period 2008-2012 and had at least 30 YFCK members. This is consistent with Fraenkel and Wallen (2000) who recommend at least 30 subjects per group. YFCK meeting attendance registers were used to obtain 316 YFCK members for the study. According to Borg and Gall (1983), the minimum recommended sample size for a survey is 100. Therefore, 175 YFCK members obtained using Proportionate sampling method was adequate for the study. The sample included $10 \%$ adjustment for mortality or refusal to participate (Balian, 1988). In addition, all the thirteen agriculture teachers from the eight selected secondary schools were used for the study.

Table 2: Summary of the Distribution of YFCK Members

\begin{tabular}{lccc} 
No. of & No. of & $\begin{array}{c}\text { Proportion of } \\
\text { YFCK Members }\end{array}$ \\
\hline Boys' Boarding & 1 & 54 & 30 \\
Girls' Boarding & 2 & 62 & 34 \\
Mixed Day & 4 & 120 & 67
\end{tabular}




\begin{tabular}{lrrr} 
Mixed Boarding & 1 & 80 & 44 \\
\hline Total & $\mathbf{8}$ & $\mathbf{3 1 6}$ & $\mathbf{1 7 5}$ \\
\hline
\end{tabular}

Source: YFCK records of selected secondary schools in Rongai Sub-County

The study employed two sets of instrument to collect data from the YFCK members and agriculture teachers. According to Orodho (2008), questionnaires are extensively used to gather data on current conditions, practices, opinions and attitudes quickly and in a precise way. The questionnaire for YFCK members consisted of three sections; Section A; yielded the demographic data of the respondent. Section B yielded data on the status of YFCK in Rongai Sub-County. Section $\mathrm{C}$ extracted data on the main activities of YFCK. The questionnaire for agriculture teachers consisted of three sections: Section A yielded data on personal information of the agriculture teachers and school characteristics. Section B provided data on performance in KCSE Agriculture in each of the schools studied over the period 2008-2012. Section C used a 5-point Likert scale to extract data on influence of YFCK activities on performance in KCSE Agriculture. The items covered were the main YFCK activities in secondary schools; competitions in ASK Exhibitions, educational trips, crop production, livestock production, national agricultural rallies and tree planting in schools. Validity is the degree to which a test measures what it is supposed to measure (Mugenda \& Mugenda, 2003). The validity of the instrument was determined through judgment of two experts from the department of Agricultural Education and Extension of Egerton University. According to Bowling and Ebrahim (2005), content validity ensured that the items adequately represented the subject area and had a relationship with the concept as operationally defined. While face validity checked on the general appearance of the items in the instrument. Pilot- testing of the instrument was carried out at Jomo Kenyatta secondary school using 62 members of YFCK. Simple random sampling method was used to adopt a sample of 50 YFCK members. This was within the recommended sample size of between 25 and 50 for a pilot-test (Kathuri \& Pals, 1993). The type of school was suitable for the study; it was a mixed boarding with separate tuition arrangement for boys and girls. The instrument on agriculture teachers was pre-tested using 10 teachers from six secondary schools in the neighboring Nakuru North SubCounty. A reliability coefficient of 0.72 for YFCK members and 0.73 for agriculture teachers at $\alpha=0.05$ was obtained. This showed there was consistency among the items. According to Fraenkel and Wallen (2000), a reliability coefficient of 0.70 set priori at a significance level of $\alpha=0.05$ or higher is preferred for research purposes.

After approval of the research proposal by the Graduate School of Egerton University, a research permit was subsequently obtained from the National Commission for Science, Technology and Innovation (NACOSTI). Permission to access public secondary schools in Rongai Sub-County was then granted by the County Director of Education Nakuru County. The questionnaires were hand-delivered to the YFCK members and agriculture teachers in each of the eight selected secondary schools in Rongai Sub-County. The researcher first introduced himself to the respondents and then explained the purpose of the study. The questionnaires were administered to each of the YFCK members and agriculture teachers. The researcher went through the questionnaires together with the respondents clarifying any issues that were not clear. The respondents were thereafter, given sufficient time to complete the questionnaires. Examination analysis records were used as a secondary source of data to capture information on the school mean scores in KCSE Agriculture between 2008 and 2012. According to Orodho (2008), data analysis involves carrying out some type of grouping of the data collected, there after placing the data in common categories and computing a number or a percentage of each division. The data collected was organized, tabulated and analyzed using descriptive and inferential statistics. Data presentations were carried out in the form of tables and graphs. All the computations were then done using Statistical Package for the Social Sciences (SPSS).

\subsection{Introduction}

\section{Data Presentation, Analysis and Discussion of Finding.}

This chapter presents the results and discussions of the study based on the objectives and hypothesis. The aspects analyzed and discussed include response rate, demographic characteristics of YFCK members and agriculture teachers, status of YFCK, the main activities of YFCK, performance in KCSE Agriculture between selected secondary schools with active and non-active YFCK, testing the hypothesis, and discussion of the results.

\subsection{Response Rate}

The research targeted a sample of 175 questionnaires for YFCK members and 13 questionnaires for agriculture teachers. From the YFCK respondents, $162(92.6 \%)$ of the questionnaires were properly filled and returned; $13(7.4 \%)$ of the questionnaires were either partially filled or not returned and were therefore discarded during data analysis. All the 13 questionnaires given to the agriculture teachers were properly filled and returned. Mugenda and Mugenda (2003) argued that a return of 50\% and above is satisfactory for data analysis. 
A return rate of $92.6 \%$ for YFCK and $100 \%$ for Agriculture teacher's respondent were considered appropriate for data analysis.

\subsection{Demographic Characteristics of the Respondents}

This section presents the distribution of the YFCK members and agriculture teachers respondents by gender, administrative Divisions, age, type and category of schools, class level, period as YFCK member, level of education and work experience.

\subsubsection{Distribution of YFCK Members by Gender}

Table 3 indicates that $52.5 \%$ of YFCK members were female and $47.5 \%$ were male.

Table 3: Distribution of YFCK Members by Gender $(n=162)$

\begin{tabular}{lcc}
\hline Gender & Frequency & Percentage \\
\hline Male & 77 & 47.5 \\
Female & 85 & 52.5 \\
\hline Total & 162 & 100.0 \\
\hline
\end{tabular}

Gender was insignificant in the implementation of the main YFCK activities in public secondary schools. Enrollment in the club was voluntary and based on students interest. This concurs with Nyang'au et al. (2011) in a study of Kisii County found gender was perceived to be the least important in the implementation of KCSE projects by learners. The notion that boys are better at manual work than girls has no basis, since boys and girls were found to be equally capable of implementing KCSE Agriculture project to the same level. However, there were slightly more girls than boys in YFCK, this contradicts a report by FAO that girls continue to be a minority among students at all levels, particularly in developing countries. The report added that existing curricula in rural schools continue to provide female students with relatively little preparation in agricultural and rural development (NRMED, 2012).

\subsubsection{Distribution of YFCK Members in Rongai Sub-County}

Table 4 shows that Kampi Ya Moto division had the highest (37.0\%) percentage of YFCK members followed by Rongai (36.4\%). Ngata division had the lowest number of YFCK $11.1 \%$.

Table 4: Distribution of YFCK Members in Rongai Sub-County $(n=162)$

\begin{tabular}{lll}
\hline Division & Frequency & Percentage \\
\hline Kampi Ya Moto & 60 & 37.0 \\
Rongai & 59 & 36.4 \\
Solai & 25 & 15.4 \\
Ngata & 18 & 11.1 \\
\hline Total & 162 & 100.0 \\
\hline
\end{tabular}

The high membership of YFCK (73.4\%) in Rongai and Kampi Ya Moto Divisions were probably due to the category of secondary schools in these Divisions (MRCSP, 2011). It had a Girls' Boarding, which was the only Mixed Boarding school. These schools had boarding facilities and therefore better infrastructure. They were categorized as County schools and had a higher enrollment of students due to a wider catchment of students in and out of the Sub-County than Sub-County schools. Ngata Division had fewer secondary schools; mainly Mixed Day secondary schools with a lower enrollment of students. The general enrollment and particularly the catchment in form one admission were confined to primary schools within the environs of the schools.

\subsubsection{Distribution of YFCK Members by Type of School}

Rongai Sub-County had four types of schools; Mixed Day, Mixed Boarding, Boys' Boarding and Girls' Boarding schools. Mixed Day schools had the highest number of respondents, 49.38\%, while Mixed Boarding schools had the lowest $10.49 \%$. It had no Boys or Girls' day schools.

Table 5: Distribution of YFCK Respondents by Type of School $(n=162)$

\begin{tabular}{lll}
\hline Type of school & Frequency & Percentage \\
\hline Mixed Boarding & 17 & 10.49 \\
Boys' Boarding & 25 & 15.43
\end{tabular}


Influence Of Young Farmers' Club Of Kenya Activities On Secondary School Students....

\begin{tabular}{lll} 
Girls' Boarding & 40 & 24.69 \\
Mixed Day & 80 & 49.38 \\
\hline Total & 162 & 100.00 \\
\hline It is important to note that agriculture option was popular in most Sub-County mixed day schools
\end{tabular}
because it was considered cost effective to start in schools with limited resources; a characteristic of many day schools in the Sub-County. All the boarding schools had lower frequencies of YFCK members probably because of competions of the various clubs already established in the schools such as Wild Life Clubs, Boy Scouts and Girl Guides, Boys' and Girls' Brigades (Adebo, 2009). On the distribution of YFCK members, data in Table 6 shows two categories of schools; County schools with $50.6 \%$ and Sub-County schools with $49.4 \%$. It is important to note that Rongai Sub-County has no National public secondary school.

Table 6: Distribution of YFCK Members by Category of Schools $(\mathrm{n}=162)$

\begin{tabular}{lcc}
\hline Category of school & Frequency & Percentage \\
\hline County & 82 & 50.6 \\
Sub-County & 80 & 49.4 \\
\hline Total & 162 & 100.0 \\
\hline
\end{tabular}

The frequency of YFCK Members in County schools is slightly higher than in Sub-County schools. All the County schools had boarding facilities and were well endowed with resources that attracted a higher enrolment of students within and outside Rongai Sub-County. The boarding facilities enabled YFCK members to have adequate time in school to engage in young farmers' club activities, unlike in Sub-County schools, which were all, composed of day schools. However, the ratio of Sub-County secondary schools to County schools was higher.

\subsubsection{Distribution of YFCK Members by Class Level}

Table 7 shows that $45.1 \%$ of YFCK respondents were in form three; while $10.5 \%$ were in form one. In the lower classes, form one, form two formed $35.2 \%$ of all the YFCK members, while $64.9 \%$ were from the upper class, which is form three, and form four.

Table 7: Distribution of YFCK Members by Class Level $(n=162)$

\begin{tabular}{lll}
\hline Class of Study & Frequency & Percentage \\
\hline Form 1 & 17 & 10.5 \\
Form 2 & 40 & 24.7 \\
Form 3 & 73 & 45.1 \\
Form 4 & 32 & 19.8 \\
\hline Total & 162 & 100.0 \\
\hline
\end{tabular}

According to KNEC (2010), Examination Regulations and Syllabuses for the KNEC 2010-2012, students are supposed to sit for a minimum of seven subjects. Agriculture is categorized as a group four subject together with other technical and applied subjects such as Home science, Art and Design, Woodwork, Metalwork, Building Construction, Power Mechanics, Electricity, Drawing and Design, Aviation Technology and Computer Studies. A student usually selects one optional subject in this group. Agriculture subject is the most popular amongst the 11 subjects in form one and two in many Sub-County day schools. This is probably because it is cheaper to offer in terms of buying equipment and other materials compared to other subjects in this category. However, this contradicts Longshal and Usman (2009), who attribute low enrollment of students in agricultural sciences, especially at secondary and tertiary levels in Nigeria as reflective of poor methods of teaching at primary school level where emphasis was put on theory. Selection of the subjects was done when students were joining form three classes. The recruitment of students to the membership of YFCK was voluntary in all classes study. According to the KLB (2009), YFCK primarily draws most of its voluntary membership from secondary and tertiary learning institutions. Recruitment of new members was carried out annually. Form three classes had good knowledge on the operations of the club thus probably attracting a large membership of students to the YFCK. In most schools visited, it was observed that most of the form fours students were busy revising for their KCSE examination and hence were unavailable. Consequently, it was observed that the low enrollment of YFCK members in form one, were probably caused by lack of information on the objectives of the club, most of the students were new and adjusting to the school environment.

\subsubsection{Distribution of YFCK Members Taking Agriculture Option}

The study revealed that a sizeable portion of YFCK members as shown in Figure $6(93.83 \%)$ took agriculture subject and another $6.17 \%$ took other optional subjects as required in the syllabus KNEC (2010). 


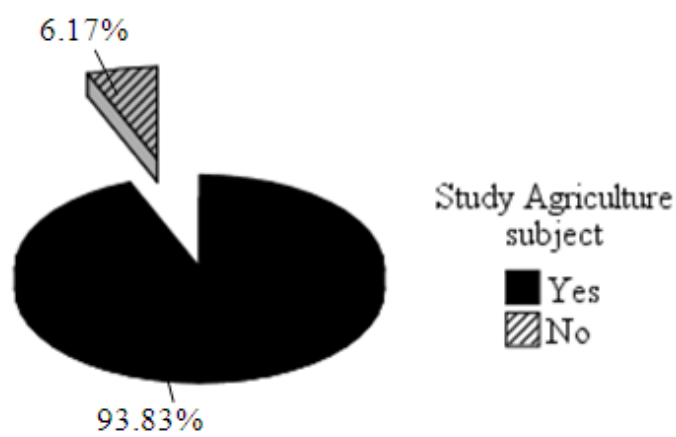

Figure 6. Distribution of YFCK Members Taking Agriculture Subject.

Though the membership of the club was voluntary, it attracted most of students who took agriculture subject option. This agrees with Lewa and Ndung'u (2011) who argued that membership to the YFCK is voluntary and gives the students exposure to practical farming technologies and opportunities in the Agricsector. In many schools, the agriculture teacher who is the patron could have influenced recruitment of the members of the club. This is in line with Agili (2007) who found out that, the agriculture teacher who acts as the patron of the club supervises the club and its activities. The low number of students who did not take agriculture option and were members of YFCK were probably attracted by out of school activities such as participation in ASK Shows, National rallies, tree planting, and educational trips. YFCK are in learning institutions that have a formally structured curriculum that is covered within a specific period. The membership is open to all Schools, Colleges, Village Polytechnics and Universities. The Out of school membership is available, but up to 30 years of age. Members above this age may serve on the executive committee of the young farmers. Agriculture often forms part of this curriculum, which enables students to gain valuable insights about sustainable agricultural production, such as in organic farming, use of clean sources of energy (biogas) and biological control of pests and diseases. It was expected that those who participate in agricultural youth programs while at school will in future not hesitate to take agriculture as an occupation (Mutambo, 2011).

\subsubsection{Distribution of Students by Years in YFCK}

The respondents were asked to indicate the length of time as members of YFCK. The number of years ranged from six months to four years, which was independent of the class of students. Table 8 shows that the majority of the students (31.5\%) had 0.6-1.2 years as members of YFCK. The lowest 3.1\% had 1.3-1.9 years in the YFCK.

Table 8: Distribution of Students by Duration in YFCK ( $\mathrm{n}=162)$.

\begin{tabular}{lll}
\hline Duration (Years) & Frequency & Percentage \\
\hline $0.6-1.2$ & 51 & 31.5 \\
$1.3-1.9$ & 5 & 3.1 \\
$2.0-2.6$ & 50 & 30.9 \\
$2.7-3.3$ & 32 & 19.8 \\
$3.4-4.0$ & 23 & 14.2 \\
\hline Total & 162 & 100.0 \\
\hline
\end{tabular}

In agriculture, there are three types of youth groups, namely: Young Farmers' Club (YFCK), 4-K Clubs, and Out-of school youth groups (Agili, 2007). However, in secondary schools, YFCK is the club engaged only in agricultural production. Every student must be a member of a certain club as per the school rules and regulations. Students usually make a choice on the club to join upon admission to the school. Registration to the YFCK is renewed annually and members are free to join other clubs of their choice. Since most members of the YFCK are drawn from students taking agriculture option, in Form Three and Form Four their membership reduces due to competition from other clubs in the school. In addition, club activities are co-curriculum activities with varied aims and membership Agili (2007), which explains the shift in membership. Students at the end of form two usually have a wide range of other subjects to choose from, which according to KNEC (2010), includes Home science, Art and Design, Woodwork, Metalwork, Building Construction, Power Mechanics, Electricity, Drawing and Design, Aviation Technology and Computer Studies. A student usually selects one optional subject in this group. 


\subsubsection{Frequency of Attendance of YFCK Meetings}

On the frequency of attendance of the YFCK meetings, an overwhelming majority of (88.3\%) stated that they attend meetings on a weekly basis. The result in Table 9 indicates that $11.1 \%$ attended the meetings monthly.

Table 9: Frequency of Attendance of YFCK Meeting $(\mathrm{n}=162)$

\begin{tabular}{lcc}
\hline YFCK Meeting Attendance & Frequency & Percentage \\
\hline Daily & 1 & 0.6 \\
Weekly & 143 & 88.3 \\
Monthly & 18 & 11.1 \\
\hline Total & 162 & 100.0 \\
\hline
\end{tabular}

On the meetings by YFCK members, the school timetable allows clubs to meet once per week as directed by the Ministry of Education. The meetings are supposed to facilitate planning, monitoring and execution of the YFCK activities. The majority (88.3\%) of the scholars pointed out that they usually met once in a week to organize YFCK activities. In other schools where the rules may be relaxed, members usually met once in a month (11.1\%). YFCK should diversify their activities, for instance, in England, members of the YFCU usually meet regularly to compare notes, discuss costs and hear talks from experts. YFCU also promotes its membership with new skills in order to realize the full potential, encourages members to take advantage of the opportunities to meet and make new friends; with members from other clubs and sister organizations throughout the world. Members enjoy a wide range of social and travel opportunities (YFCU, 2012).

\subsection{Distribution of Agriculture Teachers by Age}

The respondents age ranged from $25-44$ years $(M=38.10, S D=7.34)$ as shown in Table 10. The majority of the teachers $61.6 \%$ were aged 39 years and below. Two teachers were between 40 and 44 years.

Table 10: Distribution of Agriculture Teachers by Age $(n=13)$

\begin{tabular}{lll}
\hline Age & Frequency & Percentage \\
\hline $35-39$ & 5 & 38.5 \\
$25-29$ & 3 & 23.1 \\
$45-49$ & 3 & 23.1 \\
$40-44$ & 2 & 15.4 \\
\hline Total & 13 & 100.0
\end{tabular}

Most of the agriculture teachers in Rongai Sub-County were at their most productive age below 39 years. However, this contradicts Kimani, Kara, and Njagi (2013) who argued that teacher's age was not significantly related to academic achievement; but productivity of the teacher might be influenced by other factors such as a teacher's job group, teaching load and poor salary (Kirimi, Gikunda, Obara, \& Kibett, 2013).

\subsubsection{Distribution of Agriculture Teachers by Gender}

On the distribution of agriculture teachers by gender, Table 11 shows that $53.8 \%$ were female teachers and $46.2 \%$ were male teachers.

Table 11: Distribution of Agriculture Teachers by Gender $(n=13)$

\begin{tabular}{lll}
\hline Gender & Frequency & Percentage \\
\hline Male & 6 & 46.2 \\
Female & 7 & 53.8 \\
\hline Total & 13 & 100.0
\end{tabular}

According to Akiri and Ugborugbo (as cited in Kimani et al., 2013) there was a significant relationship between teachers gender and student's academic achievement. This concurs with Nadeem, Rana, Lone, Maqbool, Naz, and Ali (as cited in Kirimi, et al., 2013), found that poor salary, excessive workload, poor infrastructure, lack of library facilities, lack of teaching and learning material, teacher morale, working relations with staff and head teacher and working environment are the factors, which affect the female teachers performance negatively. Over $61 \%$ of agriculture teachers in Rongai Sub-County are female (MOE, 2013). All the schools in Solai Division of Rongai Sub-County have poor accessibility and are classified by the TSC as hardship area (TSC, 2005). This could be negatively affecting female teacher's performance of duty.

\subsubsection{Distribution of Agriculture Teachers by Level of Education}


Figure 7, shows two levels of education Diploma and Bachelor's degree. The majority of the teachers $76.92 \%$ had a Bachelor's degree and 23.08\% had a diploma in education.

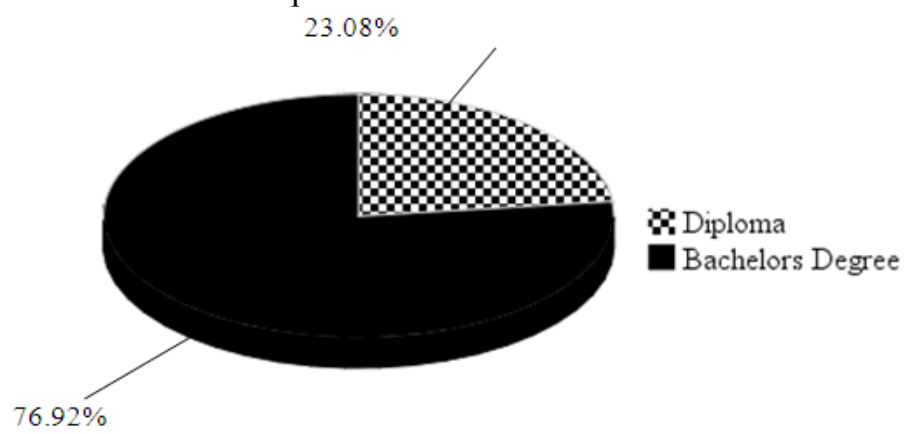

Figure 7. Distribution of Agriculture Teachers by Level of Education

There were two levels of education for the teachers; Bachelors degree, $76.9 \%$ and Diploma $23.1 \%$ of the respondents as shown in Figure 7. According to Kimani et al. (2013), academic and professional qualifications of teachers are not related to academic achievement of the learners. This is partly because the TSC employs academically and professionally qualified teachers in all public secondary schools (TSC, 2005). However, according to Kusereka (as cited in Kirimi et al., 2013) the primary factor that contributes to better performance of teachers is motivation.

\subsubsection{Distribution of Agriculture Teachers by Work Experience}

The number of years that the respondents had worked as trained teachers was regarded as work experience. The respondents work experience ranged from 1 to 24 years $(\mathrm{M}=11.38, \mathrm{SD}=7$. 08). To provide better insight, the data was converted into a grouped frequency distribution. Table 12 indicates that the majority of the teachers $69.3 \%$ had teaching experience of 15 years and less.

Table 12: Distribution of Agriculture Teachers by Work Experience ( $\mathrm{n}=13)$

\begin{tabular}{lll}
\hline Work Experience (years) & Frequency & Percentage \\
\hline $21-25$ & 1 & 7.7 \\
$16-20$ & 3 & 23.1 \\
$11-15$ & 4 & 30.8 \\
$6-10$ & 3 & 23.1 \\
$1-5$ & 2 & 15.4 \\
\hline Total & 13 & 100.0 \\
\hline
\end{tabular}

According to Clotfelter et al. (2007a); Ladd (2008); Sass (2007), (as cited in Rice, 2010) early-career experience has a clear payoff in teacher effectiveness, and the impact is stronger than the effect of most other observable teacher-related variables including advanced degrees, teacher licensure tests scores, National Board certification at the elementary level, and class size. This disagrees with Kimani et al. (2013) in the study of teacher factors influencing students academic achievement in secondary schools in Nyandarua County, Kenya, found out that teacher factors, including age, gender, professional qualification and teaching experience were not significantly related to academic achievement of the learners. However, this disagrees with Erickson (2006); Bates (1999); and Jayarante et al. (2009) who found out that work experience is a significant factor in the teaching profession as teacher gains knowledge and skills through experience. On work experience, most of the respondents had below 20 years of work experience with the highest (30.8\%) having 11-15years of experience. According to Rice (2010), in a study on "The Impact of Teacher Experience: Examining the Evidence and Policy Implications", the impact of the experience is strongest during the first few years of teaching; after that, marginal returns diminish (Greater than 25 years). The decline in performance among the most experienced teachers is evident at the high school level. In addition, multiple studies using data from North Carolina and Florida showed that, on average, teachers with 1-2 years of experience are more effective than teachers' with no experience Rice (2010). Therefore, $92.4 \%$ of the teachers in Rongai Sub-County had the required knowledge, skills and experience to impact positively on academic performance in KCSE Agriculture since they had over two years teaching experience. 


\subsubsection{Distribution of Agriculture Teachers by Type of School}

Figure 8 show that Mixed Day schools had $46.15 \%$ of the agriculture teachers. The Teachers Service Commission (TSC) usually deploys teachers in schools, according to Curriculum Based Establishment (CBE) (MOE, 2013).

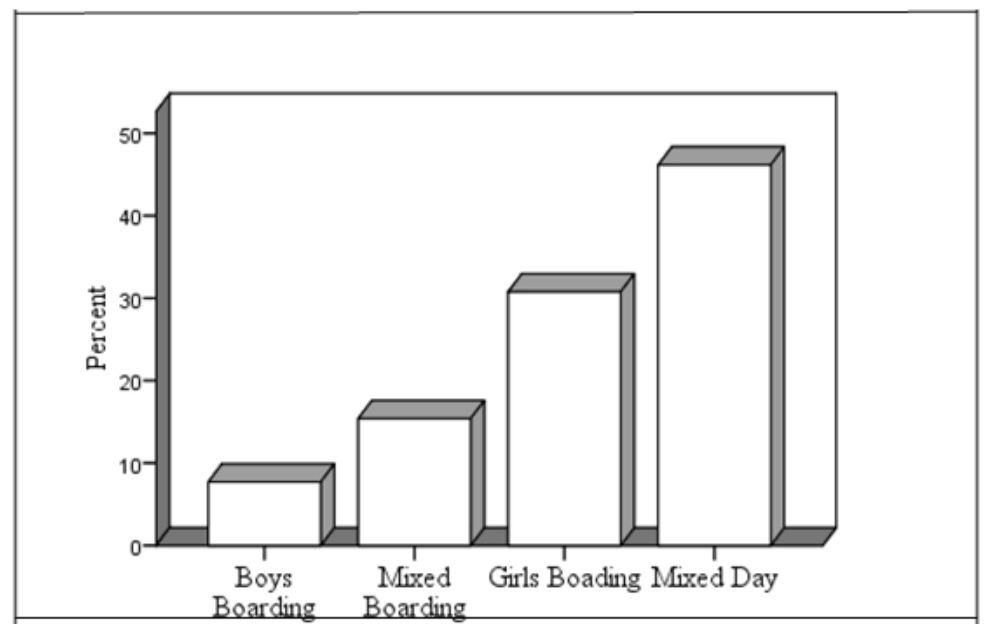

Figure 8. Distribution of Agriculture Teachers by Type of School

According to Wright, Horn, and Sanders (as cited in Kimani et al., 2013) the most important factorinfluencing student learning is the teacher. Teachers stand at the interface of the transmission of knowledge, values and skills in the learning process. The TSC has the responsibility of deploying and balancing teachers based on CBE. Most of the Mixed Day schools with a single stream had one teacher only in charge of agriculture subject, while most of the boarding schools had at least two teachers in charge of agriculture subject. The study found out that most of the boarding schools attracted teachers to work in their stations since they were accessible and had better infrastructure including teacher's quarters. This agrees with Rice (2010), who argued that studies offer compelling evidence of an uneven distribution of inexperienced teachers, that is, systematically related to school and student characteristics. Teachers with three or fewer years of experience are likely to be deployed to work in high-poverty schools.

\subsection{Status of Young Farmers' Clubs in Rongai Sub-County}

The types of activities carried out by the clubs over the last 5 years (2008-2012) in eight selected secondary schools were used to distinguish between active and non-active clubs. Table 13 shows that crop production projects is the most popular $74.7 \%$ main YFCK activity. In many schools, $48.8 \%$ of the YFCK members were from Mixed Day secondary schools.

Table13: Ongoing Crop Production Project by Type of School $(\mathrm{n}=8)$

\begin{tabular}{|c|c|c|c|c|c|c|c|c|c|c|}
\hline \multirow{3}{*}{$\begin{array}{l}\text { Grow } \\
\text { crops }\end{array}$} & & & \multirow{2}{*}{\multicolumn{2}{|c|}{$\begin{array}{l}\text { Girls } \\
\text { Boarding }\end{array}$}} & \multicolumn{2}{|c|}{ Type of school } & \multirow{2}{*}{\multicolumn{2}{|c|}{$\begin{array}{l}\text { Mixed } \\
\text { Day }\end{array}$}} & \multirow{2}{*}{\multicolumn{2}{|c|}{ Total }} \\
\hline & \multicolumn{2}{|c|}{ Boys Boarding } & & & Mix & ed Boarding & & & & \\
\hline & $\mathrm{f}$ & $\%$ & $\mathrm{f}$ & $\%$ & $\mathrm{f}$ & $\%$ & $\mathrm{f}$ & $\%$ & $\mathrm{f}$ & $\%$ \\
\hline Yes & 9 & 5.6 & 31 & 19.1 & 2 & 1.2 & 79 & 48.8 & 121 & 74.7 \\
\hline No & 16 & 9.9 & 9 & 5.6 & 15 & 9.3 & 1 & .6 & 41 & 25.3 \\
\hline Total & 25 & 15.4 & 40 & 24.7 & 17 & 10.5 & 80 & 49.4 & 162 & 100.0 \\
\hline
\end{tabular}

All the agriculture teachers' respondents strongly agreed that the main YFCK activities had a positive influence on student's performance in KCSE Agriculture. This concurs with Egun (2009); Nyang'au et al. (2011) argued that the use of projects should be encouraged in schools since it enables the learner to face challenges and bring initiatives to bear. Students taught using project based learning out-performed their counterparts in regular teaching approach. Longshal and Usman (2009) posited that agriculture is a practical oriented subject that is, best "learned by doing". Therefore, it is critical to engage learners in practical agricultural activities involving production of various types of crops covered in the syllabus. On livestock production project by type of school, slightly more than half (55.6\%) of the schools did not engage in livestock keeping. However, Table 14 shows that $44 \%$ of YFCK in Rongai Sub-County were engaged in rearing various breeds of livestock. Girls' Boarding schools had the lowest participation (5.6\%) in livestock keeping. 
Table 14: Ongoing Livestock Production Project by Type of School $(n=162)$

\begin{tabular}{|c|c|c|c|c|c|c|c|c|c|c|}
\hline \multirow{3}{*}{$\begin{array}{l}\text { Keep } \\
\text { livestock production }\end{array}$} & \multirow{2}{*}{\multicolumn{2}{|c|}{ Boys Boarding }} & \multicolumn{4}{|c|}{ Type of school } & \multirow{2}{*}{\multicolumn{2}{|c|}{$\begin{array}{l}\text { Mixed } \\
\text { Day }\end{array}$}} & \multirow{2}{*}{\multicolumn{2}{|c|}{ Total }} \\
\hline & & & \multicolumn{2}{|c|}{ Girls Boarding } & \multicolumn{2}{|c|}{ Mixed Boarding } & & & & \\
\hline & $f$ & $\%$ & $\mathrm{f}$ & $\%$ & $\mathrm{f}$ & $\%$ & $\mathrm{f}$ & $\%$ & $\mathrm{f}$ & $\%$ \\
\hline Yes & 22 & 13.6 & 9 & 5.6 & 16 & 9.9 & 25 & 15.4 & 72 & 44.4 \\
\hline No & 3 & 1.9 & 31 & 19.1 & 1 & 0.6 & 55 & 34.0 & 90 & 55.6 \\
\hline Total & 25 & 15.4 & 40 & 24.7 & 17 & 10.5 & 80 & 49.4 & 162 & 100.0 \\
\hline
\end{tabular}

According to MRCSP (2011), the Rongai Sub-County is generally arid with its main activity being sisal. This could possibly explain that it is expensive to keep livestock in terms of feeding and disease control, hence the low preference for rearing livestock. Further analysis on the types of crops grown and livestock kept, Table 15 shows that $89.5 \%$ of the YFCK preferred vegetable production, especially carrots and Kales to cereal production mainly maize and sorghum $44.4 \%$. On production of other crops such as Onions, Passion fruits and Sweet potatoes, $26.5 \%$ were involved. On livestock production, (46.9\%) preferred rearing of cattle and other type of livestock such as poultry, fish and pigs, while $32.7 \%$ of the respondents kept rabbits.

Table 15: Preference on Agricultural Activity by YFCK $(n=162)$

\begin{tabular}{llll}
\hline Type of crop/ Livestock & Frequency & Percentage & Rank \\
\hline Vegetables & 145 & 89.5 & 1 \\
Cattle & 76 & 46.9 & 2 \\
Other livestock: Poultry, & & & \\
Fish and Pigs & 76 & 46.9 & 3 \\
Cereals & 72 & 44.4 & 4 \\
Rabbits & 53 & 32.7 & 5 \\
Other crops: Onions, & & & \\
Sweet potatoes, & 43 & 26.5 & 6 \\
Passion fruits &
\end{tabular}

The highest preference for production of vegetables concurs with Agili (2007) who found that most of the youth tend to grow vegetables since they require little space to grow and mature within a relatively short period giving a quick income. YFCK cultivate crops as a group on their school plots. Livestock production ranked lowly possibly because the area is arid and feeding, parasite and disease control would have been expensive for the members. Where livestock were reared, the Board of Management supported the YFCK activity. The role of the YFCK members was to carry out routine management practices. On preference for crops by type of school, production of vegetables was highest in Mixed Day schools (43.8\%); the most popular vegetables were carrots, cabbages, kales, onions, brinjals, and tomatoes. Production of cereals was (3.1\%). Thus, it was unpopular in Mixed Boarding schools as shown in Table 16.

Table 16: Preference on Crops by Type of School $(n=162)$

\begin{tabular}{|c|c|c|c|c|c|c|c|c|c|c|}
\hline \multirow[t]{2}{*}{ Crops } & \multicolumn{2}{|c|}{$\begin{array}{l}\text { Boys } \\
\text { Boarding }\end{array}$} & \multicolumn{2}{|c|}{ Girls Boarding } & \multicolumn{2}{|c|}{ Mixed Boarding } & \multicolumn{2}{|c|}{$\begin{array}{l}\text { Mixed } \\
\text { Day }\end{array}$} & \multicolumn{2}{|c|}{ Total } \\
\hline & $f$ & $\%$ & $f$ & $\%$ & $f$ & $\%$ & $\mathrm{f}$ & $\%$ & $\mathbf{f}$ & $\%$ \\
\hline Cereals & 25 & 15.4 & 18 & 11.1 & 5 & 3.1 & 24 & 14.8 & 72 & 44.4 \\
\hline Vegetables & 25 & 15.4 & 35 & 21.6 & 14 & 8.6 & 71 & 43.8 & 145 & 89.5 \\
\hline $\begin{array}{l}\text { Others: Onions, } \\
\text { Sweet potatoes }\end{array}$ & & & & & & & & & & \\
\hline Passion fruits & 11 & 6.8 & 15 & 9.3 & 1 & 0.6 & 16 & 9.9 & 43 & 26.5 \\
\hline
\end{tabular}

Most of the boarding schools had land reserved for infrastructural development. However, this contradicts Foeken (2007), argued most boarding schools with enough land practiced farming as a way of producing their own food, in addition crop production (mainly maize and beans) was carried out by the school administration to reduce the cost of buying food for the students. This practice has become one of the ways schools respond to increases in food prices, reduced government subsidies while at the same time maintaining affordable school fees for parents. On livestock production, $27.8 \%$ of the boarding schools, reared rabbits, while 
$4.9 \%$ of Day schools reared rabbits as indicated in Table 17. Mixed Boarding schools had a high preference for keeping cattle (19.8\%).

Table 17: Preference on Type of Livestock by YFCK $(\mathrm{n}=8)$

\begin{tabular}{|c|c|c|c|c|c|c|c|c|c|c|}
\hline \multirow{3}{*}{ Type of livestock } & \multicolumn{8}{|c|}{ Type of school } & \multirow{2}{*}{\multicolumn{2}{|c|}{ Total }} \\
\hline & \multicolumn{2}{|c|}{ Boys Boarding } & \multicolumn{2}{|c|}{ Girls Boarding } & \multicolumn{2}{|c|}{ Mixed Boarding } & \multicolumn{2}{|c|}{$\begin{array}{l}\text { Mixed } \\
\text { Day }\end{array}$} & & \\
\hline & $\mathrm{f}$ & $\%$ & $\mathrm{f}$ & $\%$ & $\mathrm{f}$ & $\%$ & $\mathrm{f}$ & $\%$ & f & $\%$ \\
\hline Cattle & 24 & 14.8 & 17 & 10.5 & 3 & 1.9 & 32 & 19.8 & 76 & 46.9 \\
\hline Rabbits & 22 & 13.6 & 7 & 4.3 & 16 & 9.9 & 8 & 4.9 & 53 & 32.7 \\
\hline $\begin{array}{l}\text { Others: poultry, } \\
\text { fish and pigs }\end{array}$ & 16 & 9.9 & 9 & 5.6 & 14 & 8.6 & 37 & 22.8 & 76 & 46.9 \\
\hline
\end{tabular}

Source: Field Study Rongai Sub-County 2013

The school Board of Management had facilitated acquisition of cattle due to the high initial costs involved. These were left to YFCK members for routine management practices together with other personnel employed by the school. This concurs with Foeken (2007) found that most boarding schools with enough land practiced livestock keeping (mainly for milk). It was carried out by the school administration to reduce the cost of buying food for the students.

\subsection{Main Activities of YFCK}

On the main YFCK activities in secondary schools, data in Table 18 show that the respondents' main activity was highest $(77.8 \%)$ on crop production activities followed by tree planting $(51.9 \%)$, and the lowest $(19.8 \%)$ was YFCK National Rally.

Table 18: Main YFCK Activities by Rank $(\mathrm{n}=8)$

\begin{tabular}{lrll}
\hline Main Activities of YFCK & $\mathrm{f}$ & Percentage & Rank \\
\hline Crop Production & 126 & 77.8 & 1 \\
Tree Planting & 84 & 51.9 & 2 \\
Educational Trips & 70 & 43.2 & 3 \\
ASK Exhibitions & 68 & 42.0 & 4 \\
Livestock Production & 52 & 32.1 & 5 \\
YFCK National Rally & 32 & 19.8 & 6 \\
\hline
\end{tabular}

Most of the YFCK produced crops, especially vegetables, this is consistent with agile (2007), found that youth activities vary from one part of the county to another due to different agro-ecological zones. A main variable is in the level of moisture available for crop production. Livestock production ranked among the lowest, the result is rather unique as expectations were that it was the most popular YFCK activity and forms a major part of the syllabus. According to Foeken et al. (2007) the popularity of crops over livestock may be explained that growing of crops is not only cheaper but also easier than livestock keeping. This is in terms of feeding, disease management and day-to-day care. In addition, the school curriculum lays equal emphasis on crop and livestock production when assessing students in the agriculture project (paper 443/3). This agrees with KNEC, (2010) since paper three (443/3) on project, work is set from any topic in the syllabus. It, thus, gives equal weight to both crop and livestock production. Consequently, it implies that other factors such as security of the project, suitability of the project to local ecological conditions, weather conditions prevailing during the project period, guidance of the teacher, and student's interest were probably considered in the choice of the project to undertake.The YFCK National Rally ranked the lowest probably because most secondary school patrons of YFCK in Rongai Sub-County were not aware of its objectives. In addition, it is costly in terms of attendance by the YFCK members who normally converge from all over the Country at Jamhuri Park in Nairobi to compete on various presentations relating to agricultural production under the guidance of experts in various fields (KLB, 2009). This contradicts Agili (2007), found that ASK has the responsibility to closely monitor the YFCK activities and register them for administrative purposes. Further analysis on the main YFCK activities by school category shows that crop production was the main activity $(77.8 \%)$ performed by county and Sub-County schools in Rongai Sub-County. The lowest (19.8\%) ranked activity was YFCK National Rally. In Sub-County schools, the highest performed activity $41.4 \%$ were on crop production and the lowest $4.3 \%$ was on YFCK National Rally as indicated in Table 19. County schools performed better than Sub-County schools on competition in ASK Exhibitions (27.2\%) and livestock production (25.3\%). 
Influence Of Young Farmers' Club Of Kenya Activities On Secondary School Students....

Table 19: Main YFCK Activities by School Category $(n=8)$

\begin{tabular}{|c|c|c|c|c|c|c|}
\hline \multirow{3}{*}{ Main YFCK activities } & \multicolumn{4}{|c|}{ School Category } & \multirow{2}{*}{\multicolumn{2}{|c|}{ Total }} \\
\hline & \multicolumn{2}{|c|}{ County } & \multicolumn{2}{|c|}{ Sub-County } & & \\
\hline & $\mathrm{f}$ & $\%$ & $\mathrm{f}$ & $\%$ & f & $\%$ \\
\hline Crop Production & 59 & 36.4 & 67 & 41.4 & 126 & 77.8 \\
\hline Tree planting & 40 & 24.7 & 44 & 27.2 & 84 & 51.9 \\
\hline Educational trips & 35 & 21.6 & 35 & 21.6 & 70 & 43.2 \\
\hline Competition in ASK & 44 & 27.2 & 24 & 14.8 & 68 & 42.0 \\
\hline Livestock Production & 41 & 25.3 & 11 & 6.8 & 52 & 32.1 \\
\hline YFCK National Rally & 25 & 15.4 & 7 & 4.3 & 32 & 19.8 \\
\hline
\end{tabular}

Source: Field survey, 2013

All the Sub-County schools were day, according to Daudu et al. (2009) found the major problems that inhibit youth participation in agricultural activities were lack of commitment, lack of logistic support and lack of land ownership; factors which are common in many day schools. The low performance in most of the main YFCK activities by Sub-County schools is mainly lack of adequate land, this agrees with Wambua (as cited in Kirimi et al., 2013) found that a school farm is necessary to facilitate practical activities, projects and demonstrations. Most of the day schools had their land hived off from primary schools, hence had lower acreage compared to County schools. More than $51.9 \%$ of schools engaged in tree planting, this agrees with Foeken et al. (2007) argue that agriculture extends beyond the traditional narrow view of crop cultivation and livestock keeping. Tree planting and flower gardening has often been neglected in studies concerning farming-yet these activities, and especially tree planting may be undertaken in relation to or together with farming.

\subsection{KCSE Agriculture and School Mean scores}

The mean scores in KCSE Agriculture and School were computed by comparing means of individual secondary schools in the period between 2008 and 2012. Data in Table 20 indicate that, Boarding schools had a higher average mean score in KCSE Agriculture and in the school mean scores, while Mixed Day schools had the lowest average mean scores in both KCSE Agriculture and school mean scores.

Table 20: KCSE School and Agriculture Mean Scores 2008-2012(n=8)

\begin{tabular}{|c|c|c|c|c|c|c|c|c|}
\hline \multirow{2}{*}{ School } & \multirow[t]{2}{*}{ Type school } & \multirow{2}{*}{$\begin{array}{l}\text { KCSE } \\
\text { Mean } \\
\text { Scores } \\
\end{array}$} & \multicolumn{5}{|c|}{ KCSE YEAR } & \multirow{2}{*}{$\begin{array}{l}\text { Av } \\
\text { Mean } \\
\text { score }\end{array}$} \\
\hline & & & 2008 & 2009 & 2010 & 2011 & 2012 & \\
\hline \multirow[t]{2}{*}{$\mathrm{A}$} & Girls' & AGR & 7.45 & 8.30 & 7.07 & 7.19 & 9.13 & 7.83 \\
\hline & Boarding & $\mathrm{SCH}$ & 5.48 & 5.87 & 5.78 & 5.12 & 6.58 & 5.77 \\
\hline \multirow[t]{2}{*}{ B } & Mixed & AGR & 4.59 & 4.54 & 4.24 & 4.73 & 3.92 & 4.40 \\
\hline & Day & $\mathrm{SCH}$ & 4.10 & 3.60 & 3.97 & 4.17 & 4.00 & 3.97 \\
\hline \multirow[t]{2}{*}{$\mathrm{C}$} & Mixed & AGR & 5.39 & 4.46 & 5.5 & 5.35 & 4.79 & 5.10 \\
\hline & Boarding & $\mathrm{SCH}$ & 4.35 & 5.09 & 4.21 & 3.55 & 3.64 & 4.17 \\
\hline \multirow[t]{2}{*}{$\mathrm{D}$} & Mixed & AGR & 5.84 & 6.38 & 6.06 & 5.94 & 6.27 & 6.10 \\
\hline & Day & $\mathrm{SCH}$ & 4.28 & 4.73 & 5.25 & 5.42 & 5.10 & 4.96 \\
\hline \multirow[t]{2}{*}{$\mathrm{E}$} & Mixed & AGR & 3.92 & 4.0 & 4.53 & 4.95 & 5.05 & 4.49 \\
\hline & Day & $\mathrm{SCH}$ & 3.35 & 4.46 & 4.63 & 4.01 & 4.47 & 4.18 \\
\hline \multirow[t]{2}{*}{$\mathrm{F}$} & Mixed & AGR & 3.87 & 4.38 & 4.77 & 6.11 & 4.62 & 4.75 \\
\hline & Day & $\mathrm{SCH}$ & 3.38 & 3.65 & 3.34 & 4.75 & 3.68 & 3.76 \\
\hline \multirow[t]{2}{*}{ G } & Girls' & AGR & 7.75 & 8.25 & 6.45 & 7.31 & 7.04 & 7.36 \\
\hline & Boarding & $\mathrm{SCH}$ & 6.72 & 5.99 & 5.74 & 5.59 & 5.67 & 5.94 \\
\hline \multirow[t]{2}{*}{$\mathrm{H}$} & Boys' & AGR & 7.20 & 7.8 & 8.97 & 9.27 & 9.15 & 8.48 \\
\hline & Boarding & $\mathrm{SCH}$ & 5.30 & 5.79 & 6.55 & 7.00 & 7.05 & 6.34 \\
\hline
\end{tabular}

School type: Refer to Appendix H for specific Schools

Girls Boarding Schools performance in KCSE Agriculture were consistently higher than the school mean score over the period between 2008 and 2012 compared to Mixed Day schools whose mean scores in KCSE agriculture were lower. This concurs with Ng'eno et al. (2013) in a study in Kericho County who argued that the determinants of academic achievement in girls boarding schools included; school levies, student discipline, lack of basic needs, availability of recommended textbooks and reading culture. These limitations are likely to occur among student day scholars due to factors outside the school environment. 
Table 21: Performance in KCSE Agriculture and Type of School $(n=8)$

\begin{tabular}{|c|c|c|c|c|c|c|}
\hline \multirow[b]{2}{*}{ Type of school } & \multicolumn{5}{|c|}{ Performance in KCSE Agriculture } & \multirow{2}{*}{$\begin{array}{l}\text { Av Mean } \\
\text { Score }\end{array}$} \\
\hline & 2012 & 2011 & 2010 & 2009 & 2008 & \\
\hline Boys' Boarding & 9.15 & 9.27 & 8.97 & 7.80 & 7.20 & 8.48 \\
\hline Girls’ Boarding & 8.61 & 7.22 & 6.92 & 8.29 & 7.53 & 7.71 \\
\hline Mixed Boarding & 4.79 & 5.35 & 5.50 & 4.46 & 5.39 & 5.00 \\
\hline Mixed Day & 4.73 & 5.43 & 4.77 & 4.70 & 4.45 & 4.82 \\
\hline
\end{tabular}

Source: Field survey 2013

Table 21 shows that County schools had better performance than Sub-County schools. Kisii County found learners from county schools had better performance than their counterparts had from Sub-County schools probably because County schools are endowed with better facilities and admit students with higher marks at KCPE than Sub-County schools. This is also consistent with Ngeno et al. (2013) in a study of Kericho County, indicated that overall students from boarding schools performed better than from day schools. According to Njagi and Amukowa (2012) in a study in Embu County, who found out that day secondary schools had persistently produced poor results compared to boarding schools due to admission of weak students. This was because they were not allowed to select their students alongside the National, County, and Sub-County boarding secondary schools. Lack of teaching and learning facilities such as libraries, laboratories and other instructional materials influences academic performance negatively especially in sciences.

\subsection{Frequency of Participation in YFCK Activities}

Table 22 shows that the highest frequency of participation was Annually ( $\mathrm{f}=50$ ), followed by Every 6 months ( $f=9$ ), Every 3 months $(f=6)$ and the lowest Monthly ( $f=2)$. ASK Exhibitions and educational trips had the highest level of participation in the four types of schools. Girls' Boarding schools had the highest level of participation in all the YFCK activities. In addition, only Boys Boarding schools engaged in symposiums

Table 22: Frequency of Participation in YFCK Activities $(\mathrm{n}=8)$

\begin{tabular}{lcccc}
\hline Main YFCK Activities & Monthly & Every 3 Months & $\begin{array}{c}\text { Every } 6 \\
\text { Months }\end{array}$ & Annually \\
\hline $\begin{array}{c}\text { ASK } \\
\text { Exhibitions }\end{array}$ & 0 & 0 & 1 & 10 \\
Tree planting & 0 & 0 & 3 & 8 \\
Crop production & 1 & 2 & 1 & 9 \\
Livestock production & 1 & 1 & 1 & 7 \\
Educational trips & 0 & 3 & 1 & 10 \\
YFCK National Rally & 0 & 0 & 2 & 4 \\
Symposiums & 0 & 0 & 0 & 2 \\
\hline Total & $\mathbf{2}$ & $\mathbf{6}$ & $\mathbf{9}$ & $\mathbf{5 0}$ \\
\hline
\end{tabular}

Source: Field survey 2013

Annual participation in crop production, ASK Exhibitions, YFCK National Rally and tree planting could be attributed to dependence on seasonality, weather conditions and term dates. This agrees with Agili (2007) found that in terms of marketing, youths usually targeted harvesting time when the prices were at their highest. This is a problem when suggested growing period coincides at a time when pests and disease attacks are a problem, thus raising the total costs of production. Youth often do not have extra resources necessary to cope with the additional costs. Therefore, they tend to choose to produce crops in the rainy season along with the other farmers. ASK Exhibitions and educational trips ranked highest in participation of the main YFCK activities with $(\mathrm{f}=10)$. This shows that out of school activities were the most popular with YFCK, especially educational trips and ASK Exhibitions. According to Myers and Linda (2013), good field trips provide students with firsthand experience related to the topic or concept that is discussed in the classroom. They provide unique opportunities for learning that are not available within the four walls of the classroom or laboratory. Symposiums ranked the lowest with only one school participating in the activity. Most schools were not aware of the objectives of YFCK National rallies and the high cost of participation since the rallies are held at Jamhuri Park in Nairobi; these could have contributed to low participation of the rallies. 


\subsection{Influence of YFCK Main Activities on Performance in KCSE Agriculture}

Table 23 shows that YFCK members felt that tree planting ranked the highest $(\mathrm{M}=2.23, \mathrm{SD}=0.73)$ on its influence on students' performance in KCSE Agriculture. Livestock production projects scored the lowest $(\mathrm{M}=1.54, \mathrm{SD}=0.52)$ on the influence on students performance in KCSE Agriculture.

Table 23: Influence of YFCK Activities on Performance in KCSE Agriculture ( $\mathrm{n}=162)$

\begin{tabular}{|c|c|c|c|}
\hline \multirow{2}{*}{$\begin{array}{l}\text { YOUNG FARMERS' CLUB ACTIVITY } \\
\text { Tree planting in schools often influence students performance in KCSE }\end{array}$} & Mean & SD & Rank \\
\hline & & & \\
\hline Agriculture & 2.23 & .73 & 1 \\
\hline $\begin{array}{l}\text { Competition in ASK often influence students performance in KCSE } \\
\text { Agriculture }\end{array}$ & 1.92 & .64 & 2 \\
\hline $\begin{array}{l}\text { YFCK National Rally may influence students performance in KCSE } \\
\text { Agriculture }\end{array}$ & 1.69 & .61 & 3 \\
\hline Crop production projects may influence performance & 1.63 & .58 & 4 \\
\hline $\begin{array}{l}\text { Educational trips may influence students performance in KCSE } \\
\text { Agriculture }\end{array}$ & 1.57 & .56 & 5 \\
\hline $\begin{array}{l}\text { Livestock production projects may influence students performance in } \\
\text { KCSE Agriculture }\end{array}$ & 1.54 & .52 & 6 \\
\hline
\end{tabular}

According to Foeken et al. (2007), the prevalence of tree planting activities in most of the schools was closely linked to the wind and dust, which is common in the town due to its location on the floor of the Rift Valley with its volcanic soils. The Maasai named the place Nakurro meaning a "place of winds" or a "dusty place". It is because of this that schools plant trees to contain the winds and its effects. On competition in ASK Exhibitions, these were popular annual events in secondary schools where students acquire knowledge on modern methods of agricultural production. In addition, most YFCK members attend the event for fun. The members are given an opportunity to exhibit and judge livestock stands during the annual ASK Exhibitions. Although, the syllabus consists of two broad areas on crop and livestock production, the low score on livestock was expected since most of the YFCK in Rongai Sub-County did not engage in livestock production. This is consistent with Foeken et al. (2007) found the popularity of crops over livestock might be explained by the reason that growing crops is not only cheaper but also easier than livestock keeping. This is in terms of feeding, disease management and day-to-day care.

\subsection{Levels of YFCK Activities and Performance in KCSE Agriculture}

To gauge the perception of the respondents on YFCK activities and student's performance in KCSE Agriculture in Rongai Sub-County, the frequency of attendance of YFCK activities were related to the school and KCSE Agriculture mean scores. Each of the six main activities of YFCK was given equal weight, thus the maximum score given was six and the minimum score was one. The respondents score ranged from 12 to 36 . The midpoint was 24. School H therefore participated in YFCK activities very often $(\mathrm{f}=36)$ while school B rarely participated in YFCK activities. It had the lowest score ( $\mathrm{f}=12$ ).

Table 24: Level of YFCK Activities and Mean scores in $\quad$ KCSE Agriculture $(n=8)$

\begin{tabular}{|c|c|c|c|}
\hline $\begin{array}{l}\text { Type of } \\
\text { School }\end{array}$ & $\begin{array}{l}\text { Frequency } \\
\text { of YFCK Activities }\end{array}$ & $\begin{array}{l}\text { KCSE } \\
\text { Agriculture Mean score }\end{array}$ & $\begin{array}{l}\text { School } \\
\text { Mean score }\end{array}$ \\
\hline $\mathrm{H}$ & 36 & 8.48 & 6.34 \\
\hline A & 32 & 7.83 & 5.77 \\
\hline G & 30 & 7.37 & 5.94 \\
\hline D & 28 & 6.10 & 4.96 \\
\hline $\mathrm{C}$ & 24 & 5.10 & 4.17 \\
\hline $\mathrm{F}$ & 20 & 4.75 & 3.76 \\
\hline E & 16 & 4.49 & 4.18 \\
\hline B & 12 & 4.40 & 3.97 \\
\hline
\end{tabular}

School type: Refer to Appendix H for specific Schools.

School (H) had all the YFCK activities carried out; equally, it had the highest average mean scores in agriculture and school mean score. This could be attributed to student's exposure to practical activities through YFCK activities. This agreed with Wanjira (2009) who found out that secondary school students ability to understand, retain and apply the agricultural knowledge and skills taught improved when the teaching and learning were conducted practically. The worst performance was in school B, with the lowest levels of YFCK activities ( $\mathrm{f}=12$ ). According to Kolo (2007) and Olowa (2011), teachers of agricultural sciences still stick to antiquated teaching methods where undue emphasis is laid on theory to the detriment of practical's that is, 
supposed to equip students with basic skills and knowledge. However, performance in KCSE Agriculture in Rongai Sub-County in the sampled schools' was above the school mean scores. This indicated that agriculture subject had better performance than most other subjects offered in the curriculum.

4.11 Perception of YFCK Activities on Performance in KCSE Agriculture Items were drawn from the statements on the main activities of YFCK (livestock production projects, crop production, educational trips, national agricultural rallies, competition in ASK Exhibitions, and tree planting in schools) and whether they rarely influenced performance in KCSE Agriculture. Table 25, shows that Agricultural Livestock projects was the most key factor that influenced performance as reflected by a mean of 4.23 with a standard deviation of 0.44 . This was closely followed by educational trips and Crop production projects with a mean of 4.15(1.07) and 4.08(1.26) respectively. Other factors that influence performance in KCSE were National Agricultural rallies, Competition in ASK, and tree planting in schools with means and standard deviations of 3.69(1.11), 3.31(1.38) and 3.15(1.06) respectively. The highest expected score was five. All items had a mean above three and a standard deviation less than two.

Table 25: Perceptions of YFCK Activities on Performance in KCSE Agriculture ( $\mathrm{n}=13$ )

\begin{tabular}{llll}
\hline Items & Mean & Std. Deviation & Rank \\
\hline $\begin{array}{l}\text { Livestock } \\
\text { Production projects }\end{array}$ & 4.23 & 0.44 & 1 \\
Educational Trips & 4.15 & 1.07 & 2 \\
$\begin{array}{l}\text { Crop Production } \\
\text { Projects }\end{array}$ & 4.08 & 1.26 & 3 \\
$\begin{array}{l}\text { YFCK National } \\
\text { rallies }\end{array}$ & 3.69 & 1.11 & \\
$\begin{array}{l}\text { Competition in ASK } \\
\text { Exhibitions }\end{array}$ & 3.31 & 1.34 & 4 \\
Tree planting & 3.15 & 1.06 & 5 \\
\hline Survey 2013 & & & 6 \\
\hline
\end{tabular}

Source: Field Survey 2013

Livestock production project was the most popular activity in the calendar of YFCK. The climax of the ASK Exhibitions is the Stockman's competition, which probably could have popularized attendance to the Show by members of YFCK. According to Agili (2007), the clubs function under the auspices of the Agricultural Society of Kenya (ASK), they receive technical support from the Ministry of Agriculture through agricultural extension field staff. Registered YFCK members receive a wide range of benefits derived from the parent organization such as; space to exhibit without paying rent during the Show, agricultural tours, and cash prizes in Stockman's competition among others. On whether educational trips hardly influenced performance in KCSE Agriculture, it was the second most important factor. This agrees with Lewa and Ndung'u (2011), found that membership to the YFCK, is voluntary and gives the students exposure to practice farming technologies and opportunities in the Agric-sector through visits to modern forms. The use of educational field trips has long been a major part of the educational programming for both youth and adults. However, due to funding limitations, time constraints, and increased liability concerns, many education professionals balk at requests for field trips. In spite of these concerns, well-planned educational field trips can be a valuable tool in equipping the participants with modern agricultural production methods (Myers \& Linda, 2013). Crop production projects had a high influence on performance in KCSE Agriculture. The mean score was high and ranked at position three. This could be attributed to the reason that paper one (443/1) in KCSE Agriculture tests on general agriculture, crop production, agricultural economics, land and water management (KNEC, 2010). Accordingly, project paper $443 / 3$ requires a candidate to undertake a project on crop production as stipulated by KNEC from year to year. All the agriculture teacher respondents agreed that livestock production projects often influenced performance in agriculture. This agrees with KNEC (2010) syllabus, Paper two (443/2) that entails agricultural theory and practices in reference to livestock production, farm power, farm machinery, farm structures, farm tools and equipment. Agriculture subject is practical oriented and its effective teaching requires the learner participation in the various activities by actual 'doing'. Secondary school students' ability to understand, retain and apply the agricultural knowledge and skills taught were enhanced when the teaching and learning are conducted practically. Teachers can often use the school farm to conduct practical agriculture lessons and demonstrations. This agrees with Wambua, (as cited in Kirimi et al., 2013) who says that a school farm is necessary to facilitate 
practical projects and demonstrations. In many secondary schools YFCK are used to conduct practical activities for agriculture lessons. National Agricultural rallies had a moderate influence on performance in KCSE Agriculture. The reason could be failure by the ASK officials to articulate properly the objectives of the rallies to the YFCK patrons. The YFCK National Rally was held once in a year. YFCK members from all over the country converged at Jamhuri Park in Nairobi to compete on various presentations relating to agricultural production under the guidance of experts in various fields. On competition in ASK Exhibitions, the influence on performance in KCSE Agriculture was moderate. The ASK Show is usually held annually in each of eight regions. The show is associated with fun, merrymaking, and not a serious forum for study by YFCK members. This contradicts KLB, (2009) which, states that one of the main functions of ASK is to organize YFCK; whose functions include participating in exhibitions and competitions at ASK Shows. The study found out that most of the clubs rarely participated in these exhibitions. In addition, those that did had fewer exhibits not well organized. Tree planting had the lowest influence on performance in KCSE Agriculture. This is in spite of the syllabus covering a substantial part of agro-forestry across all the four levels of secondary school syllabus. According to KNEC, (2010) tree planting is covered under agro- forestry. The study found out that it was carried out in most schools during the rainy season. This disagrees with Foeken et al., (2007), who argued that tree planting and flower gardening has often been neglected in studies concerning farming-yet these activities, and especially tree planting may be undertaken in relation to or together with farming. On whether belonging to YFCK helped to improve performance in agriculture examinations, all the agriculture teacher respondents agreed. According to Nyang'au et al. (2011); Wambugu and Changeiywo, (2008) students taught using project based learning out-performed their counterparts in regular teaching approach. The teachers gave various reasons, citing the practical activities in the syllabus that require projects. From the data, all the agriculture teachers agreed to have integrated the YFCK activities in the teaching of agriculture. However, this did not agree with the students response where $59.9 \%$ said that agricultural projects do not account for any credit in any examination. The $40.1 \%$ who agreed had $19.8 \%$ citing KCSE examination and $16 \%$ citing the end of term examinations. This agrees with the KCSE project paper three (443/3) that is compulsory and contributes marks in the final grade in KCSE Agriculture (KNEC, 2010). The grading system in the internal examinations varied depending on the category of the school. The grading of Sub-County schools was slightly lower than for county schools. However, where schools sat for joint examinations, the grading system was standardized. The grading in KCSE Agriculture is standardized for all the schools in Kenya.

\subsection{Comparison of Active and Non-Active YFCK}

The significant difference between the mean scores of schools in with active and non-active YFCK was determined using t-test. The null hypothesis $\left(\mathrm{H}_{01}\right)$ stated that there was no statistically significant difference between the mean scores in KCSE Agriculture of schools with active and non-active YFCK. The frequency of participation in the main YFCK activities (Crop production projects, livestock production projects, YFCK National Rally, competition in ASK Exhibitions, and Educational trips) were used to differentiate between active and non-active clubs. In order to determine if a significant difference existed between schools with active and non-active YFCK, a t-test was applied. The results in Table 26, indicated that there was no significant difference between the mean scores in KCSE agriculture of schools with active and non-active YFCK ( $p=0.507$ at 0.05 significant levels). The data supported the null hypothesis and it was therefore accepted since the $t$-value of 0.686 was not significant at $\alpha=0.05$; that is ( $p>0.05$ ). This means that the $p$ value was large and, therefore the obtained difference between the sample means was not significant.

\begin{tabular}{|c|c|c|c|c|c|c|}
\hline \multicolumn{7}{|c|}{ Table 26: T-test Analysis between Active and Non-Active YFCK $(n=13)$} \\
\hline $\begin{array}{l}\text { YFCK } \\
\text { Participation }\end{array}$ & $\mathrm{n}$ & $\begin{array}{l}\text { Mean scores in } \\
\text { KCSE Agriculture }\end{array}$ & Std. Deviation & df & t-value & p-value \\
\hline Active & 7 & 6.3174 & 1.70944 & 11 & .686 & .507 \\
\hline Non active & 6 & 5.6987 & 1.50785 & & & \\
\hline
\end{tabular}

Significance level $=0.05$

In testing the null hypothesis $\left(\mathrm{H}_{01}\right)$, the t-test analysis showed that there was no evidence of a statistically significant difference between secondary school student's performance in KCSE Agriculture in schools with active and schools with non-active YFCK. The findings of the study indicates that YFCK has no influence on performance in KCSE Agriculture which, does not agree with Mukebo (2013) who argued that students mainly join the YFCK to improve on academic performance, for personal interest, and to gain life skills. Though the study emphasizes on the use of practical activities in teaching of agriculture subject, YFCK are viewed like any other co- curriculum activity that exist in secondary schools. According to Agili (2007) club activities are extra-curriculum activities with varied aims and membership; preferably to acquaint students to modern agricultural methods, careers, and as a means of creating student interest in agriculture (Mbaga, 1996; KNEC, 2010). It is a requirement that every student must be a member of a club in a secondary school. 
According to Kalya, (2012) there are no compulsory requirements for membership and participation. Most students join the clubs voluntarily to enjoy out of school activities such as tours, ASK Shows, YFCK National camps and National rallies but are not committed to learning activities. This agrees with results in Table 22, where Agricultural Show Exhibitions and Educational trips had the highest frequency of participation $(\mathrm{f}=10)$. This further, agrees with Phipps et al. (2008) who argued that in the USA, FFA is an educational program designed to teach students leadership skills in both agricultural settings, encourages personal growth in students, boosts self-confidence, builds character, encourage healthy lifestyles, and give students opportunities to be a part of the agricultural economy.

\section{Conclusion of the Study}

Based on the results of the study, the researcher concluded that:

i Although most public secondary schools had YFCK, the level of YFCK member's participation in the main activities was still low. Participation in crop production projects ranked highest in most schools.

ii There was no difference in KCSE mean scores in agriculture subject between schools with active and nonactive YFCK.

iii Participation in YFCK National Rally among the YFCK activities was very low.

iv The KCSE Agriculture mean scores in schools in the study were better than the overall school mean scores.

\section{Recommendations}

Based on the findings and conclusions of the study, the researcher recommends:

a) The Ministry of Education should:-

i YFCK activities should be integrated adequately across all the levels in the syllabus.

b) The Agriculture teachers should:-

i. Ensure YFCK are active by enforcing the school routine and the curriculum.

ii Liaise with ASK for effective implementation of the YFCK National Rally, which currently has low participation in many schools.

c) The school Board of Management (BOM) should:-

i Facilitate projects on livestock projects that have low participation in many schools by providing financing.

\section{References}

[1]. Adebo, M. (2009). Youth Organization in Agriculture. National Open University of Nigeria 14/16 Ahmadu Bello Way. Victoria Island, Lagos. Retrieved January 20, 2012,from URL.www.nou.edu.ng.

[2]. Agili, A. (2007). Expert consultation on extension, rural and sustainable agriculture. A paper on Educational content and delivery systems related to the youth Agricultural Society of Kenya (2010). Historical perspective. Retrieved Septembr 17, 2011, from http://www.ask.co.ke/.

[3]. Amiran Kenya, (2010). Face Book Farmers. Retrieved February $2^{\text {nd }}$, 2012, from http://ww w.amirankenya.com/index.php

[4]. Atherton, J. S. (2010). Experiential Learning Cycle. Learning and Teaching. Retrieved on $9^{\text {th }}$ February, 2011 from http://www.learni ngandteaching.info/ learning/ experience. htm

[5]. Baker, A. M. \& Robinson, S. J. (2012). Aligning Kolb's Experiential Learning Theory with a Comprehensive Agricultural Education Model. Journal of Agricultural Education, 53 (4): 1-16. Retrieved on 10 ${ }^{\text {th }}$ March, 2011 from Dio: 10.5032/Jae. 2012.04001

[6]. Balian, E. S. (1988). How to Design, Analyze, and Write Doctoral or Master's Research. NY: University Press of America.

[7]. Bates, A. W. (1999). The impact of new media on knowledge. Vancouver, B.C: University of British Columbia Borg, W. R. \& Gall, M. E. (1983). Educational Research. An Introduction. New York, NY: Longman Inc pp.257-265.

[8]. Bowling, A. \& Ebrahim, S. (2005). Handbook of Health Research Methods: Investigation, Measurement and Analysis. Open Univer sity Press. Retrieved on $19^{\text {th }}$ May, 2011 from https://www.google.com/search?q=bowling\%26ebrahim $+2005 \& i e=u t f 8 \& o e=u t f-$ $8 \&$ aq $=$ t\&rls= org.mozilla:en-US:official\&client $=$ firefox-a

[9]. Bryan, L. G., Dyer, J. E. \& Brad, O. K. (2001). Factors Associated with the Academic Performance and Retention of College Agriculture Students. Do: 6521 1-7040 NACTA Journal-March 2001 Retrieved on $2^{\text {nd }}$ March, 2014 from http://www.nactateachers.org/attachments/article/581/Dyer. NACTA Journal March 2001-3.pdf

[10]. Cheek, J. G., Arrington, L. R., Cater, S. \& Randell, R. S. (2010). Agricultural experience Program Participation and Student Achievement in Agriculture. Journal of Agricultural Education, 35 (2): 1-5. Retrieved on $10^{\text {th }}$ March, 2011 from day: 10.50321 jae. 1994.02001

[11]. Conlan, J., Grabowski, S. \& Smith, K. (2003). Adult Learning. In M. Orey (Ed.), Emerging perspectives on learning, teaching, and technology. Retrieved on $9^{\text {th }}$ February, 2011, from http://projects.coe.uga.edu/epltt/

[12]. Daudu, S., Okwoche, V. \& Adegboye, O. (2009). Role of Youths in Agricultural Development in Makurdi Local Government Area of Benue State Journal of Agricultural Extension: 13 (2) Retrieved on 2/3/2014 from, http://ypard.net/news/youth-organizationsrelated-agricultural-research-development-ard-world

[13]. Dictionary.com Online, (2009). Retrieved on May 13, 2012 from http://www.hsl.unc.edu/services/Tutorials/ATA/researchdesign.

[14]. Egun, A. E. (2009). Educational Futurism: A Case for the Teaching of Agricultural Education for Youths in Nigeria. Department of Vocational Education, Delta State University Abraka. Nigeria. International Journal of Education, Science, 1 (1): 53-60. Retrieved J une 25, 2012, from https://docs.google.com/viewer?a=v\&q=cache:znLYQbdmB51J:www.1

[15]. Farm Africa, (2012). Youth Empowerment through Sustainable Agriculture (YESA). Retrieved May 5, 2012, from http://www.farmafrica.org.uk

[16]. Foeken, D., Owuor, S. O. \& Mwangi, A. M. (2007). School farming and school f e e d i n g in Nakuru town, Kenya Practice and potential. ASC Working Paper 76/2007. African Studies Centre 2300 RB Leiden: The Netherlands. 
[17]. Fraenkel, J. R. \& Wallen, N. E. (2000). How to Design and Evaluate Research in Education, NY: Mc Grawhill.

[18]. Hantos, K. (2010). Promoting an Effective Change of Generations in Agriculture Supporting Young Farmers. (Unpublished Ph.D dissertation). Corvinus-University Budapest.

[19]. Hedjaz, Y. \& Omidi, M. (2008). Factors Affecting the Academic Success of Agricultural Students at the University of Tehran, Iran. Journal of Agricultural science and Technology, (10), 205-214. Retrieved on June 13, 2012, from https://docs.googlcom/viewer?a=v $\& q=$ cache:OjDvN4j4h54j.www.si

[20]. Herblin, D. (2012). Youths hold key to food security, UN report tells Kenya. Business. Daily Friday May 18, 2012. Retrieved May 23, 2012, from http://www.- businessdailyafrica.com/-/539444/rdynki//index.html.

[21]. Jones, A. (2011). Importance of Education, About. Comguide. Retrieved January 4, 2011, from physics.about.com//2011/./theimportance-of-education.

[22]. Kathuri, J. \& Pals, A. (1993). Introduction to Educational Research. Educational Media Centre (ECM), Egerton University: Kenya.

[23]. Kalya, A. (2012). Agricultural Society of Kenya. Retrieved June 26, 2012, from, http://www.ask.co.ke/about-ask/chairman-sreview.

[24]. Kendall, D. (2007). Sociology in our times: The essentials, (p. 39). USA. Thomson Wadsworth.

[25]. Kenya Literature Bureau (KLB). (2012). Secondary Agriculture Form one Students' Book. (Third Edition). ISBN 9966-44-620-6. Kenya Literature Bureau.

[26]. Kenya Literature Bureau (KLB). (2009). Secondary Agriculture Form Four Students' Book. (Third Edition). ISBN 9966-44-620-6. Kenya Literature Bureau.

[27]. Kenya National Examinations Council (KNEC). (2010). Examination Regulations and Syllabuses for the Kenya Certificate of Secondary Education (KCSE) Examination 2010-2011. KNEC, City Square, Nairobi: Kenya.

[28]. Kimani, N. G., Kara, M. A. \& Njagi, W. L. (2013). Teacher Factors Influencing Students' Academic Achievement in Secondary Schools in Nyandarua County, Kenya. International Journal of Education and Research, 1 (3): 1-14. Retrieved on 19 February,2014.Fromhttp://edoqs.net/pdf/teacher-factors-

influencing students academic achievement-0a422ce4309f3 f8b25ac08b8c8da93b2

[29]. Kirimi, F. K., Gikunda, M. R., Obara, J., \& Kibett, J. (2013). Influence of Selected Motivational Factors on the Performance of Secondary School Agriculture teachers in Imenti South Sub-County. Kenya International Journal of Education and Research, 1 (6): June 2013 .

[30]. Kolo, E. (2007). The Significance of Teacher Education on the Teaching and Learning of Agricultural Science in Nigerian Schools Zuba Journal of Vocational Education,1(2), 154167. Retrieved June 25, 2012 from http:s//docs.google.com/viewer?a=v\&q=cache:8 BYXeoUwdAYJiwww.

[31]. Laogun, E. A. (2002). Rural Youth Training Needs for Rural Community Development. Nigerian Journal of Rural Sociology, 3: (2) $57-63$

[32]. Lewa, K. K. \& Ndung'u, J. M. (2011). Does educational level influence the choice of farming as a livelihood career? Results of an empirical study from coastal low land Kenya.

[33]. Longshal, M. W. \& Usman, M. (2009). Achieving the Millennium Development Goals by2015 through Effective Teaching of Agricultural Science in Nigeria. The Voice of Teachers, (1), 2009.

[34]. Macho, M. (2008). Assessment of Practical Skills Subjects with Particular Reference to Technical Institutes and Schools. Uganda National Examinations Board Kampala, Uganda. Retrieved May 27 ${ }^{\text {th }}, 2013$ from 22110935_31.doc

[35]. Mangal, H. (2009). Best Practices for Youth in Agriculture: The Barbados, Grenada and St Lucia Experience.

[36]. Mbaga, L. M. (1996). Assessment of formal agricultural education in Coast Province (Unpublished PhD Thesis). Pennsylvania State University.

[37]. McLintock, A. H. (2009). Young Farmers'Clubs: the Dominion Federation, from an Encyclopedia of NewZealand.TeAra-the Encyclopedia of New Zealand. Retrieved June 25, 2012, from http://www.TeAra.govt.nz/en/1966/farmers.

[38]. Ministry of Education (MOE) (Republic of Kenya), (2013). Rongai Sub-County. Education/prize giving day- 2013. Unpublished manual.

[39]. Ministry of Food \& Agriculture, (MOFA). (2013). Republic of Ghana. Retrieved on 10/2/2014 from, http://mofa.gov.gh/site/?page id $=12426$

[40]. Modern Rongai Constituency Strategic Plan (MRCSP) (2011-2017), (2011) Total Project Consultants Limited and Modern Rongai Constituency CDF: Books Limited: Nairobi. Unpublished.

[41]. Mudulia, M. A. (2012). The Relationship between Availability of Teaching/Learning Resources and Performance in Secondary School Science Subjects in Eldoret Municipality, Kenya. Journal of Emerging Trends in Educational Research and Policy Studies. 3(4): 530-536. Retrieved on February $10^{\text {th }} 2014$ from, http://idosi.org/aejaes/jaes 10\%284\%29/5.pdf.

[42]. Mugenda, M. O. \& Mugenda, G. A. (2003). Research Methods Quantitative and Qualitative Approaches. African Centre for Technology Studies (ACTS) Press. Nairobi: Kenya

[43]. Mukebo, S. (2013). The Views of Young Farmers Clubs Members on Their Clubs' Activities, Their Career Interests, and Their Intentions to Pursue Agriculture-Related Career Preparation at Post-Secondary Level: An Embedded Case Study of Two Secondary Schools in Eastern Uganda. Retrieved on August 22, 2014 from http://gradworks.umi.com/15/42/1542215.html

[44]. Mutambo, A. (2011). Bid to Renew Interest in Agriculture Through Secondary School Contests. Daily Nation Friday May 13, (P17). Nation Media Group Ltd: Nation Centre, Kimathi Street: Nairobi.

[45]. Mwangi, W. M. (2013). School Based Factors' Influence on Students' Performance in Kenya Certificate of Secondary Education in Murang'a South Sub-County, Kenya. University of Nairobi. Kenya Information Preservation Society (KIPS) Unpublished MA. Thesis.

[46]. Myers, B. \& Linda, J. (2013). Effective Use of Field Trips in Educational Programming: A Three-Stage Approach Department of Agricultural Education and Communication at the University of Florida. Retrieved 2/3/2014 from,https://edis.ifas.ufl.edu/pdffiles/W C/WC05400.pdf

[47]. Natural Resources Management and Environment Department [NRMED] (2012). Report of an expert consultation on rural youth and young farmers in developing. Agricultural Education and Extension Service, Human Resources, Institutions and Agrarian Reform Division, FAO: Rome.

[48]. National- 4 H. (2012). History Preservation Team. International 4-H History continum Retrieved June 25, 2012 from http://4hhistor ypreservation.com/History/international Programs.

[49]. National Federation of Young Farmers' Clubs (NFYFC). (2011). History of Young Farmers' Clubs. Retrieved October 25, 2011, http://legacy.nfyfc.org.uk/. 
[50]. Ngeno, C. V., Simatwa, M. W. \& Soi, C. D. (2013). Determinants of Girl Students' Academic Achievement in Mixed Day and Boarding Secondary Schools in Kericho County: International Research Journals Research (ISSN: 2141-5161) 4 (7) 543-554, $\mathrm{http} / /$ www.interesjournals.org/er/july-2013-Vol4-issue-7/determinants-of-girl-students-academic-achievement-in-mixed-da

[51]. Njagi, K. \& Amukowa, W. (2012). Analysis of Factors That Lead To Poor Performance in Kenya Certificate of Secondary Examination in Embu County in Kenya. School of Education Mount Kenya University. Retrieved from http://www.tijoss.com/TIJOSS\%2013th\%20Volume/Amukowa.pdf

[52]. Northern Illinois University. (2011). Experiential learning. Faculty Development and Instructional Design Center 815.753.0595. Retrieved February 19,2014 from http://epltt.coe.uga.edu/index.php?title=Experiential_Learning

[53]. Nsa S.O., Ikot, A. S. \& Udo, M. F. (2013). Instructional materials utilization and students' performance in practical agriculture. Journal of Educational Research and Reviews Vol.1(4),pp.49-54,ISSN:2315-

9859Research Paper. Retrieved on 27/2/2014 from http://www.sciencewebpublishing.net/jerr/archive/2013/December/pdf/Nsa\%20e t\%20al.pdf

[54]. Nyang'au, M. K., Kibet, J. K. \& Ngesa, F. U. (2011). Perceptions of School Principals and Agriculture Teachers towards Factors Influencing Initiation of Secondary School Agriculture Projects. Middle East Journal of Scientific. Research 9(4):546553, ISSN199 0233. Retrieved June 25, 2012 from http:s//docs.google.com/viewer? $\mathrm{a}=\mathrm{v} \& \mathrm{q}=$ cache:XTrapBxAYzOJ: www.id

[55]. Olowa, O. W. (2011). Effects of Problem Solving and Subject Matter Approaches onthe Problem Solving Ability of Secondary Sch ool Agricultural Education. Journal of industrial Teacher Education Volume, (46), 132-145. Retrieved May 21, 2012 from h ttp://scholar.lib.vt.edu/ejournals/jite/v46n1/olowa.

[56]. Olujide, M. G. (2008). Attitude of Youth towards Rural Development Projects in Lagos State, Nigeria. Department of Agricultural Extension and Rural Development, University of Ibadan, Nigeria.

[57]. Orodho, J. A. (2008). Techniques of Writing Research Proposals and Reports in Education and Social Sciences, Second Edition, Maseno, Kanezja HP Enterprises.

[58]. Oxford Advanced Learner's Dictionary, (2011). $8^{\text {th }}$ Edition. New York, NY: Oxford University press.

[59]. Phipps, L. J., Osborne, E. W., Dyer, J. E. \& Ball, A. L. (2008). Handbook on agricultural education in public schools. Clifton Park, NY: Thomson Learning, Inc.

[60]. Rice, J. K. (2010). The Impact of Teacher Experience Examining the Evidence and Policy Implications. National Center for Analysis of Longitudinal Data in Education Research. Urban institute, $2100 \mathrm{M}$ Street, N. W. Washington, D.C. 20037. Retrieved June 21, 2013 from http://www.urban.org.A

[61]. Richard, C. (2012). Experiential Learning. Retrieved May 21, 2012 from, http://www.innovativelearning.com/people/richardcullata.html

[62]. Roberts, G. T. \& Harlin, F. J. (2007). The Project Method in Agricultural Education: Then and Now. Journal of Agricultural education,3 (48): 40-46. RetrievedMay 2, 2012 from http://docs.google.com/viewer?a=v\&q=cache:8BYXeoUwdAJiwww.j

[63]. Shannon, A., Wendy, J. W. \& Edward, W. O. (2006). Experiential learning in secondary Agricultural Education Classrooms. Journa 1 of Southern Agricultural Education Research 56, (1): 2006. University of Florida.

[64]. Sternberg, R. J. \& Zhang, L. (2000). Perspectives on cognitive, learning, and thinking styles. NJ: (Eds.), Lawrence Erlbaum.

[65]. Teachers Service Commission (TSC) (2005). Code of Regulation for Teachers. www.tsc.go.ke

[66]. Texas Young Farmers. (2007). Education Leadership Development Community Service Recreation. Servant Leadership.

[67]. Visel, C. T. (2008).Vocational Agriculture Education and Students with Learning Needs. New Haven Teacher Evaluation Process 2008-2009 School Year. Retrieved June 25, 2012, from http://docs.google.com/viewer?a=v\&q= cache:OQAy-2Ba5swJ:www.si

[68]. Wambugu, P. W. \& Changeiywo, J. M .2008. Effects of Mastery Learning Approach on Secondary School Students Physics' Achievement. Eurasian Journal of Mathematics, Science \& Technology Education. 4 (3), E-Issn:Dio 13058223

[69]. Young Farmers' Club of Ulster (YFCU). (2012). Retrieved June 25, 2012, from http:// www.yfcu.org/club finder.

[70]. Young People and Agriculture. (2009). Rural radio resource. Pack No 02/1 WREN Media, Fressing field, Eye, Suffolk, IP21 5SA, UK. Retrieved January 2, 2012 from https//docsgogle.com/viewer www.anancy.net/doc. 